The proceedings in the arts theatre then ended, and Lord Onslow and the council and senate and guests walked through the university grounds to the new zoology buildings, where, after a short speech by Prof. Herdman, Sir John Murray addressed the assembly upon oceanography. Mr. R. B. Haldane also delivered a brief speech, in the course of which he remarked that by obtaining the grant of $200 l$. from the Chancellor of the Exchequer Sir Thomas Elliott had established a principle and connected the University of Liverpool with His Majesty's Government.

The Department of Zoology.

The Derby chair of natural history was established by the fifteenth Earl of Derby in $188 \mathrm{I}$-an appropriate gift from a descendant of the scientific founder ${ }^{1}$ of the celebrated zoological collections once alive at Knowsley and now secured to Liverpool in the Derby Museum of the Public Galleries. The first Derby professor was appointed at the end of $I 88 \mathrm{r}$, and thus natural history was one of the three or four scientific departments with which University College opened in January, 1882 . The work of the Liverpool Marine Biology Committee has been so intimately bound up with the Natural History Department during the last twenty years that, although not, strictly speaking, a part of the university organisation, it is impossible to omit a brief record of its history. Established for the purpose of exploring the fauna and flora of Liverpool Bay and the neighbouring parts of the Irish Sea, it brought a number of the local field-naturalists into close relation with the university department and laboratory methods, it gave rise to dredging expeditions and observations and experiments at sea, which led on in later years to sea-fisheries investigations, and it resulted in the accumulation of collections which have proved of considerable interest and scientific value. The "local" collection in the museum of the new buildings has been almost wholly obtained through the work of the L.M.B.C.

Probably the most important outcome of this exploring work has been the establishment of a marine biological station on the west coast of England. After five years' use of an old Dock Board observatory on Puffin Island, off Anglesey, the committee moved their marine station to Port Erin, at the south end of the Isle of Man, where they have now a substantial, new, two-storeyed building, measuring 95 feet by 45 feet, containing laboratories, an aquarium, and a fish-hatchery, and provided with a large, open-air, sea-water pond for the spawning and rearing of fish. As to the results obtained from this institution (which is under the direction of the Derby professor, and is worked in connection with the university department), it will suffice to state that during the last year thirty-six investigators worked in the laboratory, about five millions of young plaice were sent out to sea from the fish-hatchery, and more than thirteen thousand visitors paid for admission to the aquarium.

It was certainly to this marine biological work in the past that the natural history department owed in the first instance that connection with the local sea-fisheries authorities which has recently developed into a formal agreement between the university and the Lancashire and Western Sea Fisheries Committee. The scientific work of the local fisheries district is carried on in the laboratories by assistants paid by the Fisheries Committee, and the professor has been appointed honorary director of the scientific work, and furnishes an annual report on the work of the fisheries laboratory. A share of the laboratory accommodation in the new buildings will be devoted to the furtherance of the work of the Liverpool Marine Biology Committee, of the Lancashire and Western Sea Fisheries Committee, of economic entomology, and of other useful applications of zoology.

It has been recognised for some years that the accommodation in the old college buildings was quite inadequate to meet the wants of this department, and although some extensions had been made, such as a wooden fisheries laboratory on the roof and a convenient little museum (given about ten years ago by the late Mr. George Holt), these were temporary expedients which in some ways only emphasised the pressing need for new and much larger

1 The thirteenth Farl of Derby, President of the I innean Society, 1828I8?3, and subsequently President of the Zoological Society. buildings. Research work offered to the department was hampered, and in some cases had to be declined for want of room. These facts were given expression to in the statements of needs drawn up in connection with the university movement of Igor-2, and after the establishment of the university a sum of $18,000 l$. was voted to the council by the university committee in October, 1902, for the purpose of erecting and equipping a new department of zoology, to contain a museum and a lecture theatre, the necessary students' laboratories, and also accommodation for sea fisheries investigations and other lines of marine biological research.

\section{The New Buldings.}

This zoological institute has a frontage of 123 feet on the western side of Brownlow Street, is $4 \mathrm{I}$ feet from fron to back, and 84 feet in height from the street level. It is built of red pressed brick relieved with white sandstone from the Storeton quarries in Cheshire. The building consists of a central tower containing the entrance hall and staircase and some of the smaller rooms on each floor, and of two blocks, the north and the south, which have been treated rather differently as regards internal structure. The south block has only three main floors, while the north has five in the same height. The central tower extends a storey higher. In the south block the three floors accommodate (I) the museum with its large gallery; (2) the lecture theatre; and (3) the large junior laboratory at the top of the building. In the north block, on the two lower floors there are extensions of the museum to receive special collections, and the rest of the space is devoted to the senior class-room, senior and honours students' laboratories, the departmental library, and rather large laboratory and store-room accommodation for the sea fisheries department, the work of the economic entomologist, of the marine biological committee, and other practical applications of zoology. In the central tower, along with the staircase, there are small rooms for the professor and two demonstrators, the laboratory assistant, with diagram, chemical, aquarium, photographic, macerating rooms and students' lavatories.

GEOLOGY AT THE BRITISH ASSOCIATION

I $\mathrm{N}$ Section $\mathrm{C}$ the papers read were largely on subjects of local interest, and in many cases by South African geologists. The delivery of the presidential address in this section having been fixed for the meeting at Johannesburg, the proceedings at Cape Town were opened with a short address of introduction by the president, followed by a lecture by $\mathrm{Mr}$. A. W. Rogers, the director of the Colonial Geological Survey, on the outlines of the geology of the Cape Colony.

Among the subjects discussed, the Karroo claimed a considerable share of attention. Prof. R. Broom, in a paper on the classification of the Karroo beds, retained the division into Dwyka, Ecca, Beaufort, and Stormberg series. He subdivides the Beaufort series into three, and the Stormberg into two parts on reptile evidence, and correlates the various divisions with European strata thus:-Dwyka and Ecca series with Lower and Middle Permian, Lower Beaufort beds with Upper Permian, Middle and Upper Beaufort beds with Lower and Upper Trias, Lower Stormberg beds with Rhætic, and Upper Stormberg beds with Lower Jurassic.

Mr. A. L. du Toit gave an account of the Stormberg formation in Cape Colony. This uppermost division of the Karroo beds consists of a considerable thickness of nearly horizontal sandstones, shales, and volcanic rocks, and includes (in descending order):-(4) Volcanic Beds; (3) Cave Sandstone; (2) Red Beds; (1) Molteno Beds. The formation covers a considerable area in the east of the colony, in the Stormberg and Drakensberg districts, the summits of the mountains being commonly formed of the lava flows of (4). The sediments were deposited in an inland sea, the "Karroo Lake," the southern shore-line of which ran along the present coast-ranges of the colony, and thence north-eastward, outside and parallel with the coast-line of Natal. The author suggests the correlation of the Volcanic Beds and Cave Sandstone with the Rájmahál series of India (Middle? and Lower Jurassic), and of the Molteno beds with the Kota-Maleri series of India and the Wianamatta series of New South Wales (Rhætic). 
Prof. A. Young described a remarkable case of an artesian well in the Karroo which shows a daily fluctuation in its discharge. The curve obtained during some weeks by a self-recording apparatus is very regular, and has a period of almost exactly $12 \frac{1}{2}$ hours. The amplitude shows a marked variation, corresponding in time with the phases of the moon, and analogous to marine spring and neap tides. The outlet is more than 2700 feet above sea-level, and the author suggests that the water, which contains a large amount of inflammable gas, is forced up from a great depth through fissures by the pressure of natural gas, and that the observed fluctuation is a minor effect, due to the moon, superimposed on the effect of the constant gas-pressure. The phenomenon is scarcely affected by barometric changes.

At a joint meeting with the Geographical Section on the second day, Mr. H. C. Schunke-Hollway gave an account of the physical geography of Cape Colony. Mr. Rogers read a paper on Glacial periods in South Africa, in which he described the glacial deposits of Table Mountain Sandstone- (Silurian?) and of Dwyka- (Carboniferous) age, each formed of materials derived from the north. There is no satisfactory evidence of glacial action in later times, the glaciated forms of certain hills in Griqualand West, cited by Stow, being now known to have been produced at any rate not later than Dwyka times, since similar forms may be traced underneath the surrounding Dwyka conglomerate. They have been preserved by a thick covering of Dwyka and other beds, which have only recently been removed.

Prof. A. Penck (Vienna) contributed a paper on changes of climate as shown by variations of the snow-line and upper tree-limit since Tertiary times, in which, from a consideration of the geological evidence as to the relative height of the snow-line and tree-line in Glacial times, he drew conclusions as to the cause of the glacial conditions. The facts pointed to a lowering of temperature as the cause of the glaciation rather than to an increase of precipitation. Prof. Penck suggested that an examination of the higher parts of the Drakensberg might probably reveal traces of a Pleistocene Ice age in South Africa, though hitherto satisfactory evidence of this has been wanting.

Prof. W. M. Davis, of Harvard, brought forward evidence for the sculpture of mountains by glaciers. ${ }^{1} \mathrm{He}$ based his arguments principally upon the marked difference in form between valleys proved in other ways (e.g. by the presence of striations) to have been once glaciated, and those which have not been glaciated, the differences being in nature and distribution such as glaciers would cause on the assumption that they could erode.

Papers were also read by Prof. Sollas, on the continent of Africa in relation to the physical history of the earth; by Prof. J. Milne, on recent advances in seismology; by Mr. E. H. L. Schwarz, on "Baviaan's Kloof, a Contribution to the Study of Mountain Folds"; and by Mr. H. T. Ferrar, on the geology of South Victoria Land, giving the results of his observations on Antarctic rocks and glaciers made during the voyage of the Discovery.

Prof. Sollas sketched a possible way in which the present distribution of oceans and continents on the globe may have arisen. The earth is not strictly a spheroid, but resembles an ellipsoid, of which the shortest axis passes through the poles, while the longest lies in the plane of the equator and emerges in Central Africa. The distribution of land and water is such as would obtain if the earth had the form of a pear which had been somewhat compressed in the direction of its core, and thereby caused to bulge laterally. Africa would be situated on the broad end of the pear, and would represent the remains of the primeval continent-a supposition consistent with the known absence of marine sediments over the greater part of the interior, notwithstanding the thick accumulations of flat-bedded strata existing there.

Mr. Schwarz's paper contained an account of a remarkable piece of geological structure observed in the valley of the Baviaan's River, a tributary of the Gamtoos River, in the neighbourhood of Port Elizabeth. On the Baviaan's River occur certain outliers of Enon conglomerate (Creta-

1 The papers by Prof. Penck and Prof. Davis will be published shortly in the Geographical Journal.

No. 1882 , voL. 73$]$ ceous) which have been found by bore-holes to occupy steepsided, basin-shaped depressions with no outlet, in Palæozoic rocks of the Bokkeveld and Witteberg series (Cape system). The basins are bounded by faults or steep dipslopes, and are explained as having been formed by two series of cross-foldings trending E.S.E. to W.N.W. and N.E. to S.W., which took place while the country was covered with the Enon conglomerate, the latter being faulted down upwards of 1000 feet. The author objects to the usual explanation of rock-folding as produced by a direct tangential thrust against an obstacle, caused by shrinkage of the earth's crust, and suggests that it may in fact be gradually produced by earthquake-waves travelling through one kind of rock (say sedimentary beds resting on granite) and encountering a mass of rock having a different modulus of elasticity (as, for example, a boss of the underlying granite). The effect of this would be to heap up the strata in folds against the obstacle, somewhat as when waves break on the shore.

At Johannesburg a considerable number of the papers were, appropriately, of mineralogical and petrographical interest.

The proceedings opened with the delivery of the presidential address by Prof. Miers (Nature, August 24, vol. 1xxii. p. 405).

Prof. J. W. Gregory followed with two papers of special interest to gold miners. In one of these, on the Rhodesian Banket, he stated that he had found during a recent examination of the district that the name had been applied to several different rocks which are locally auriferousnot only to an undoubtedly sedimentary conglomerate forming the main mass of the material, but also to crushconglomerates and breccias, and to a diorite dyke with segregations of amphibolite. The Rhodesian conglomerate may probably be rightly called Banket, but differs considerably from the Banket of the Rand in its fluviatile origin, the greater variety in size and composition of the pebbles, and its probably greater age. The question as to the right of the Rhodesian deposit to the name of "Banket" aroused considerable discussion.

In his second paper (on the Indicators of the goldfield of Ballarat-a study in the formation of gold pockets) Prof. Gregory showed the secondary origin of the so-called "indicators," or thin iron-stained bands, which traverse the slaty country-rock of Ballarat and lead to rich pockets of gold at the points where they intersect the otherwise barren quartz reefs. The indicators are shown by microscopic and field evidence to be narrow seams of chlorite or rutile needles, which are not quite, though, as a rule, nearly, parallel to the bedding, and cannot therefore be of sedimentary origin.

Prof. R. Beck, of Freiberg, gave a summary of recent investigations on the origin of pegmatites as products of the crystallisation of the residual mother liquors of a solidified plutonic magma. Certain ore-veins have been formed thus as metalliferous pegmatites, for example the tin veins of Zinnwald and Embabaan, the copper ores of Telemarken and the auriferous quartz-reefs of Berezowsk, the Yukon district and Passagem, and other places in Brazil. The presence of tourmaline in certain gold-quartzes bears out this view of their origin.

Prof. A. P. Coleman, of Toronto, dealt with the magmatic segregation of sulphide ores. The recent complete mapping of the eruptive sheet with which the nickel-ore deposits of Sudbury (Ontario) are all connected, shows that the Sudbury ore is, like the pyrrhotite nickel ores of Norway described by Vogt, really a product of segregation from the rock, of which it forms an integral part with every gradation between ore and rock. Gravitation has probably played a large part in the segregation process.

Prof. Grenville A. J. Cole read a paper on marginal phenomena of granite domes, in which he upheld the view that banded gneissic rocks are due rather to the incorporation of the surrounding rocks with the materials of an invading granite than to simple dynamic metamorphism; the banding is produced by igneous flow, and is especially marked in cases where the absorbed rocks were sedimentary or already foliated.

On the second day Mr. G. W. Lamplugh gave his report of a journey, made under the auspices of the association to examine the zigzag gorge of the $Z_{\text {aumbesi }}$ 
below the Victoria Falls, from which he had just returned. Mr. Lamplugh, who penetrated down stream for a distance of 70 miles from the Falls, accepts and confirms the explanation given by Mr. Molyneux, of Bulawayo, who attributes the zigzags to the guidance of the stream-erosion by transverse joints in the basalt plateau through which the gorge has been cut.

Prof. Penck read a paper, illustrated by a fine series of lantern slides, on the Glacial deposits of the Alps.

Mr. Kynaston, director of the Geological Survey of the Transvaal, gave an account of the recent work of the survey. Since its re-organisation in 1903, the attention of the survey has been chiefly occupied with the later formations forming the central portion of the country, and the results obtained bear testimony to the able way in which the work has been carried on. The igneous complex of the Bushveld to the north of Pretoria may be mentioned as forming an interesting petrographical province. It illustrates the differentiation of a magma, in what is probably an enormous laccolite, intruded between the Pretoria and Waterberg series, into zones of increasing basicity, ranging from the red granite of the central region to the norites, pyroxenites, serpentine, and magnetiterock of the margin.

Dr. F. H. Hatch explained the views arrived at by Dr. Corstorphine and himself as to the correlation between the pre-Karroo beds of the Transvaal and those of Cape Colony ("Geology of South Africa," 'I905). Dr. Hatch also exhibited an instrument, devised by Mr. Oehmen, for surveying bore-holes, that is, for determining the amount and direction of the inclination of the bore-hole to the vertical at any given depth-a problem of considerable importance in a country where diamond drilling is so largely used as in South Africa, as a deep bore-hole may deviate as much as $30^{\circ}$ or more in its lower levels.

The Rev. S. S. Dornan gave an account of his observations on the geology of Basutoland. The rocks belong to the Stormberg series, and consist of sandstones, mudstones, and shales forming the Molteno Beds and the overlying " Red Beds." Fossils are rare, but a few plant and reptile remains have been found in the former. Above the Red Beds lies the Cave Sandstone, a thick-bedded sandstone, which forms the crests of the hills and contains caves sometimes showing Bushman paintings. Reptile tracks are frequent, but few other fossils occur. The higher ridges of the Drakensberg and Maluti ranges are formed of lava-flows and intrusive sheets belonging to the volcanic series. This communication was of special interest on account of the difficulty of making observations and collecting fossils in Basutoland, as it is a native reserve, and the natives are unwilling to allow any prospecting, fearing lest they might lose their country should gold be discovered.

On the last day of the meeting Mr. C. B. Horwood read a description of the Dolomite formation, which is important as being practically the only source of underground water supply in the Transvaal. The rock is probably a deep-sea deposit, which has subsequently undergone dolomitisation in shallow water, and has lost in the process all trace of organic remains, so that its age is unknown. Mr. W. Anderson contributed a paper describing the first Tertiary rocks of marine origin which have been discovered in South Africa. These comprise sands, marls, and shales, with marine Mollusca (identified as probably of Eocene age) and Foraminifera in the upper beds, while in the lowermost shales occur numerous isolated bones of Mammalia (elephant, rhinoceros, hippopotamus, \&c.), with water-worn fragments of fossil wood, and fish and crustacean remains. The beds, which are confined to the coast of Natal and Zululand, are probably of estuarine origin. A calcareous grit, forming the Bluff at Durban, is also probably Tertiary in age.

A paper by Mr. E. T. Mellor dealt with the evidences in the Transvaal of glacial conditions in Permo-Carboniferous times, and the distribution of the glacial conglomerates forming the base of the Karroo system, which corresponds to the Dwyka conglomerate of Cape Colony. Here, as in the country to the south, the striations, as well as the nature of the boulders, point to a northerly origin. Mr. Lamplugh read a note on the occurrence of Dwyka conglomerate at Kimberley Mine.

No. 1882 , voL. 73$]$
In a paper on the diamond pipes and fissures of South Africa, Mr. H. S. Harger expressed his view that the source of the diamond lay in a zone of ultra-basic rocks -eclogites, lherzolites, and pyroxenites-in which it may be an original constituent crystallising from the magma, for it has been frequently found in garnets and more rarely in olivine, and has been produced artificially in the latter. The blue ground filling the diamond pipes and the associated fissures is an altered breccia formed by the shattering of these ultra-basic diamondiferous rocks during a period of volcanic activity, probably in late Triassic or Jurassic times. Mr. Harger's paper was especially valuable as embodying the results of careful personal observations carried on through several years on the occurrence and associations of the diamond in the numerous mines scattered up and down the country, some of which are little known outside South Africa. An interesting collection of specimens of the associated minerals was on exhibition in the adjoining museum.

Papers were also communicated to the meeting by $\mathrm{Dr}$. J. T. Carrick, on the geology of the West Rand; by Mr. F. P. Mennell, on the plutonic rocks and their relations to the crystalline schists; and by $\mathrm{Mr}$. E. Heneage, on a consideration of the Archæan period of North America and South Africa with reference to mineral occurrences.

Apart from the papers read, a more than usual amount of interest attached this year to the geological excursions, of which a large and most interesting series were organised by Dr. Molengraaff, Prof. R. B. Young, and Mr. Rogers, to whom, with the, other gentlemen who acted as leaders, the thanks of the section are especially due.

These excursions--many of which occupied several days and were on a scale hitherto unprecedented, except possibly at the Toronto meeting in 1897 -afforded the members of the Geological Section a unique opportunity of seeing the most interesting features of the country under the guidance of the men by whom they had been investigated, members of the various surveys being spared for the purpose by their respective Governments.

After the meeting at Cape Town Mr. Rogers led a party through the Karroo, visiting, among much else of interest, the folded ranges of the Hex River district, and exposures of the Dwyka conglomerate (or Boulder-clay) and of the Beaufort beds which have yielded Pareiasaurus and other characteristic reptiles. While in Natal, several members visited the glaciated surfaces and overlying beds at Vryheid, under the guidance of $\mathrm{Mr}$. W. Anderson, the Government geologist, and Dr. Molengraaff, formerly State geologist of the Transvaal. During the meeting in Johannesburg a number of afternoon excursions were made to the gold mines and other points of interest, while after its conclusion several more extended expeditions took place. These included one to Vereeniging, under $\mathrm{Dr}$. Hatch, to examine the sandstones and coal-seams of the Ecca series, which have yielded the Glossopteris flora, and the associated beds, and to see Mr. T. N. Leslie's collections of fossil plants from the Ecca sandstone and of flint implements from the Vaal River. Another party had an opportunity of studying the norites and syenites of the Plutonic complex of the Bushveld, at the Pyramids and in the neighbourhood of the Pienaar's River, to the north of Pretoria, under Mr. Kynaston and Mr. A. L. Hall; while a third party, with Mr. Hall and Mr. Frames, visited the Duivels Kantoor, at the eastern edge of the Transvaal plateau, where the escarpment of the Black Reef series and Dolomite overlooks the floor of Archran rocks, on the denuded surface of which they rest unconformably.

Excellent opportunities were also afforded of studying the occurrence of the diamond, both at the Premier and other Transvaal mines, under Mr. Cullinan, the chairman of the Premier Diamond Company, and Messrs. Hall, Harger, Kynaston, and Trevor, and at Kimberley through the kind offices of $\mathrm{Mr}$. Gardner Williams, the chairman of De Beers.

In addition to this, there was a great deal of interest to the student of surface geology to be seen during the long train journey, among which may be mentioned the hillcountry in the north of Natal, the flat and sandy bushscenery along the line to the north, and the wonderful examples of weathering in the granite country of the Matopo Hills. 